\title{
Organic selenium supplementation is cost-effective for increasing the number of seminal doses produced by sexually mature boars
}

\author{
Simone Maria Massami Kitamura Martins ${ }^{1,3}$, Esther Ramalho Afonso ${ }^{1}$, Larissa José Parazzi², \\ André Furugen Cesar de Andrade ${ }^{3}$, Diego Feitosa Leal ${ }^{3}$, Augusto Hauber Gameiro' ${ }^{1}$, Aníbal de \\ Sant'Anna Moretti ${ }^{1}$, Rubens Paes de Arruda ${ }^{3+}$

\footnotetext{
${ }^{1}$ Universidade de São Paulo, Faculdade de Medicina Veterinária e Zootecnia, Departamento de Nutrição e Produção Animal, Pirassununga, SP, Brasil.

${ }^{2}$ Universidade Federal do Oeste da Bahia, Centro Multidisciplinar da Barra, Barra, BA, Brasil.

${ }^{3}$ Universidade de São Paulo, Faculdade de Medicina Veterinária e Zootecnia, Departamento de Reprodução Animal, Pirassununga, SP, Brasil.
}

\begin{abstract}
The present experiment was carried out to evaluate the economic viability of supplementing boar diets with organic selenium aiming to increase the number of seminal doses of sexually mature boars. Twelve boars were divided into three groups: control group received $0.3 \mathrm{mg} \mathrm{kg}^{-1} \mathrm{Se}$ from sodium selenite $(\mathrm{n}=4)$, inorganic group received $0.5 \mathrm{mg} \mathrm{kg}^{-1} \mathrm{Se}$ from sodium selenite $(\mathrm{n}=4)$, and organic group received $0.5 \mathrm{mg} \mathrm{kg}^{-1}$ Se from Sel-Plex ${ }^{\mathrm{TM}}$ (Alltech, Inc., $\mathrm{n}=4$ ). The experiment was conducted within 10 weeks and analysis was performed fortnightly. No interaction was observed between treatments and weeks for any of the variables analyzed. Boars fed diet supplemented with $0.5 \mathrm{mg} \mathrm{kg}^{-1}$ of organic selenium exhibited a $23 \%$ increase in the seminal doses, which resulted in a $37 \%$ reduction in the cost of diet per dose produced by boars in this group compared with boars in the inorganic group. It should be pointed out that the total revenue produced by the organic group was $26 \%$ higher than the inorganic group. The feeding of organic Se increases the number of seminal doses and reduces the average cost of the diet, demonstrating to be cost-effective.
\end{abstract}

Key Words: cost production, organic mineral, swine

\section{Introduction}

Microminerals are known to exert beneficial effects on the reproductive function of both males and females and, therefore, have drawn great interest of numerous researchers in the past years aiming to acquire a better understanding of their function and their different sources in animal diets (Kiefer, 2005).

As far as the key role of selenium (Se) in sperm development and functionality is concerned, a number of studies have been conducted to investigate the effects of supplementing boar diets with $\mathrm{Se}$ on reproductive characteristics (Marin-Guzman et al., 1997, 2000a, 2000b); in the same way, the effect of different sources of Se on raw semen (Lopez et al., 2010; Lovercamp et al., 2013) as well as on chilled semen (Speight et al., 2012) has also been investigated. Moreover, other studies have evaluated the

Received: November 1, 2016

Accepted: June 26, 2017

*Corresponding author: arrudarp@usp.br

Copyright (c) 2018 Sociedade Brasileira de Zootecnia. This is an Open Access article distributed under the terms of the Creative Commons Attribution License (http://creativecommons.org/licenses/by/4.0/), which permits unrestricted use, distribution, and reproduction in any medium, provided the original work is properly cited. association between Se supplementation and sources $(0.3$ and $0.5 \mathrm{mg} \mathrm{kg}^{-1}$; sodium selenite and Se-yeast) regarding plasma and acrosome membrane integrity, mitochondrial membrane potential, as well as on the activity of the phospholipid hydroperoxide glutathione peroxidase (PHGPx) of raw (Martins et al., 2014) and chilled semen (Martins et al., 2015).

The requirements of swine for Se varies depending on environmental conditions; however, in general, 0.15 to $0.30 \mathrm{mg} \mathrm{kg}^{-1}$ feed is considered the ideal amount to attend their nutritional requirements. It is noteworthy that reproducing sows and boars are especially sensitive to Se deficiency, which poses a challenge to pig nutritionists (Close and Cole, 2000). In nature, Se exists in two chemical forms, organic and inorganic (selenite, selenate, and selenide). Over the last few decades, the commercial technology for organic Se production from yeast has been developed and this source of Se proved to be effective for poultry and other farm animals alike (Surai, 2006).

Currently, the choice between inorganic or organic minerals should be based on a careful economic evaluation, since the latter can be costly, requiring a cost-benefit analysis prior to its use (Kiefer, 2005). On this path, despite several studies carried out in which boars received diets supplemented with trace minerals, very few have 
truly evaluated the economic viability of their outcome. Hence, the objective of this study was to determine the economic viability of supplementing diets with organic Se regarding the production of seminal doses of sexually mature boars.

\section{Material and Methods}

Experiments were carried out in accordance with Animal Care and Use Committee (case number 1426/2008). The trial was performed in Pirassununga, São Paulo, Brazil $\left(21^{\circ} 49^{\prime} \mathrm{S}\right.$ and $\left.47^{\circ} 25^{\prime} \mathrm{W}\right)$.

Twelve sexually active boars (Agroceres PIC) were housed in individual pens of $9.76 \mathrm{~m}^{2}$ animal $^{-1}$, with concrete flooring and within the same building during all experimental period; before the start of the trial, they received a commercial feed containing inorganic $\mathrm{Se}$ $\left(0.3 \mathrm{mg} \mathrm{kg}^{-1}, 2.0 \mathrm{~kg}\right.$ boar day $\left.{ }^{-1}\right)$.

Prior to the experiment, two independent clinical examinations accompanied by morphological and physical (motility and vigor) analysis of seminal characteristics were performed on each animal in accordance with guidelines of the Colégio Brasileiro de Reprodução Animal (CBRA, 1998). The results of two ejaculates were used to prepare a score determined for each boar; thus, the boars were assigned blocked by quality semen, using the following equation:

Score boar $=3 \times$ Sperm major defects $+2 \times$ Sperm minor defects $+1 \times$ Progressive motility inverse

Boars were allocated into three treatments: control, $0.3 \mathrm{mg} \mathrm{kg}^{-1}$ sodium selenite; inorganic, $0.5 \mathrm{mg} \mathrm{kg}^{-1}$ sodium selenite; and organic, $0.5 \mathrm{mg} \mathrm{kg}^{-1}$ selenium as Sel-Plex ${ }^{\mathrm{TM}}$ (Alltech, Inc.), fed approximately $2.6 \mathrm{~kg}$ boar day ${ }^{-1}$ (NRC, 2012). Six samples $(0,2 \mathrm{nd}, 4$ th, 6th, 8th, and 10th weeks) were collected, fortnightly, via the gloved-hand technique and filtered to remove the gel fraction before evaluation of semen characteristics.

The volume was determined based on weight to semen. Sperm concentration analysis was performed in a Neubauer chamber after 1:100 dilution in formaldehydephosphate buffered saline solution. Total number of sperm per ejaculate (TSE) was obtained by multiplying sperm concentration by volume and total motility. The number of seminal dose was calculated by division of TSE and seminal dose concentration $\left(3 \times 10^{9}\right.$ spermatozoa $\left.100 \mathrm{~mL}^{-1}\right)$.

For sperm motility assessment, the CASA system (HTM-IVOS-Ultimate; Hamilton Thorne Biosciences, Beverly, MA, USA) was pre-adjusted for swine semen analysis. Semen samples were pre-warmed at $37^{\circ} \mathrm{C}$ for $15 \mathrm{~min}$ and $2 \mu \mathrm{L}$ of each sample $\left(25 \times 10^{6}\right.$ spermatozoa $\left.\mathrm{mL}^{-1}\right)$ were dispensed on $20 \mu \mathrm{m}$ standard count analysis chambers (SC20.01.FA; Leja, Nieuw-Vennep, The Netherlands). Six fields were randomly selected for analysis of total and progressive motilities (\%); average path, straightline, and curvilinear velocities $\left(\mu \mathrm{m} \mathrm{s}^{-1}\right)$; amplitude of lateral head displacement $(\mu \mathrm{m})$; beat/cross frequency $(\mathrm{Hz})$; straightness $(\%)$; and linearity $(\%)$ as described by Celeghini et al. (2008).

The sodium selenite requirement for boars is $0.3 \mathrm{mg}$ $\mathrm{kg}^{-1}$ and lower quantities can lead to deficiency; for this reason, the supplementation was calculated based solely on the difference between supplementation and nutritional requirement, considering the additive itself. The economic analysis was based on food intake of each treatment together with the value spent with the additive for each diet. Each treatment represented three distinct production technologies. There were no changes on allocating work and capital since management, equipment, and facilities were all similar among treatments.

The prices of the pelleted feed ( $\left.\mathrm{R} \$ 2.00 \mathrm{~kg}^{-1}\right)$, seminal dose (R\$ 6.00 dose $\left.^{-1}\right)$, sodium selenite $(45 \%$ Se; R 128.18 $\left.\mathrm{kg}^{-1}\right)$, and the additive Sel-Plex (1\% Se; at the price tag of $\mathrm{R} \$ 20.40 \mathrm{~kg}^{-1}$ ) were all based on the market price of July 2013. The additive price was obtained directly from Alltech Inc. The formulae used to calculate each treatment were as follows:

Total cost of diet $(\mathrm{TCD})=$ Feed cost + Additive cost

Cost per dose $(\mathrm{CD})=\mathrm{TCD} \div$ Number of seminal dose

Total revenue $(\mathrm{TR})=$ Price of doses $\times$ Number of seminal dose

The TCD was calculated considering the period of 42 days, in which these data were collected. Then, this value was divided by 6 to correspond to the same weekly period used to obtain the number of seminal doses. The CD was calculated considering the number of seminal doses produced in the same period of seven days.

Data were analyzed using the MIXED procedure of SAS (Statistical Analysis System, version 9.3) according to a block design containing treatments as main factors. Each animal was considered as one experimental unit. Treatments were evaluated using orthogonal contrast to analyze treatment effects: contrast $1(\mathrm{C} 1)$ referred to the effect of supplementation and contrast $2(\mathrm{C} 2)$ referred to the effect of source. Effects were considered significant when $\mathrm{P}<0.05$ and all results were expressed as means \pm standard error of the mean. Effect of time was analyzed using the REPEATED statement in a PROC MIXED model of SAS. 


\section{Results}

The results regarding volume, sperm concentration, total number of sperm, and total motility were published according to Martins et al. (2014).

The organic group presented a higher $(\mathrm{P}<0.05)$ TSE compared with the inorganic group (83.26 and $61.61 \times 10^{9}$ sperm ejaculate $^{-1}$, respectively). No difference was found between control and inorganic + organic groups. This higher value of TSE resulted in higher seminal doses $(\mathrm{P}<0.05)$ for the organic group compared with inorganic group (25.23 vs. 19.53 doses, respectively); thus, boars fed diet supplemented with $0.5 \mathrm{mg} \mathrm{kg}^{-1}$ of organic selenium exhibited a $23 \%$ increase in seminal doses (Table 1). In addition, the seminal doses also differed according to supplementation $(\mathrm{P}<0.05)$ between control and inorganic + organic groups (17.04 vs. 22.41 doses, respectively), which led to an increase of $24 \%$ in favor for the supplemented diet.

Regarding the economic analysis, the amount of organic additive used per kilogram of feed was greater when compared with the inorganic source; moreover, the price of the organic additive was greater than the inorganic source, contributing to greater participation in the diet cost ( $0.051 \%$ and $0.003 \%$, organic and inorganic, respectively).

Although the cost of the organic Se diet was more expensive than the inorganic Se diet ( $\mathrm{R} \$ 36.51$ vs $\mathrm{R} \$ 36.41$ total cost of diet, respectively), the cost of diet per seminal dose exhibited the lowest cost $(\mathrm{P}<0.05)$ due to a greater production of seminal doses of boars fed the organic source ( R\$ 1.52 vs R\$ 2.40 cost per dose, organic vs inorganic group, respectively), which resulted in a $37 \%$ reduction $(\mathrm{P}<0.05)$ in the cost of diet per dose produced by boars fed organic Se compared with those fed the inorganic Se. No difference was observed between control and inorganic + organic groups ( $\mathrm{R} \$ 2.33$ and $\mathrm{R} \$ 1.96$ cost per dose, respectively) regarding this characteristic (Table 1).

It should be pointed out that the total revenue produced by the organic group was $26 \%$ higher than the inorganic group $(\mathrm{P}<0.05), \mathrm{R} \$ 151.40$ and $\mathrm{R} \$ 111.54$, respectively. No difference was observed between control and inorganic + organic groups, regarding this characteristic (Table 1).

\section{Discussion}

Concerning the key role of Se in sperm development and functionality, several studies have been conducted to investigate the effects of Se supplementation on boar reproductive characteristics (Marin-Guzman et al., 1997, 2000a, 2000b) as well as the effect of different sources of Se on raw (Lopez et al., 2010; Martins et al., 2014) and chilled semen (Speight et al., 2012; Martins et al., 2015).

In the present experiment, the increase in the number of seminal doses produced by boars fed diet supplemented with organic Se might be a result of the role played by organic $\mathrm{Se}$ in establishing the number of spermatozoa reserves and Sertoli cells, as verified by Marin-Guzman et al. (2000a). In their study, boars fed diet supplemented with 0 or $0.5 \mathrm{mg} \mathrm{kg}^{-1}$ of Se for 18 months and they found that testicular sperm reserves were higher in boars fed the higher Se diet. In addition, boars fed dietary Se had also a greater number of Sertoli cells and round spermatids at 6.2 months of age, and by 18 months, they also presented a greater number of secondary spermatocytes.

Our results showed that boars fed diet supplemented with organic Se exhibited a higher volume of ejaculate $(\mathrm{P}>0.05)$ as well as higher sperm concentration $(\mathrm{P}>0.05)$, resulting in greater $(\mathrm{P}<0.05)$ total sperm per ejaculate. The current results could only partially confirm the results of previous studies, in which boars fed an organic Se diet, when compared with boars receiving an inorganic Se diet, exhibited a significantly higher sperm concentration (Marin-Guzman et al., 1997; Jacyno et al., 2002; Lopez et al., 2010) and also higher total sperm per ejaculate (MarinGuzman et al. 1997; Jacyno et al., 2002). Such an increase in the number of seminal doses were observed in boars fed a diet supplemented with Se from an inorganic source; however, when Se obtained from an organic source was used as supplementation, it resulted in higher seminal doses produced, which, in turn, reduced the cost of diet per dose,

Table 1 - Characteristics of semen of boars fed diet supplemented with inorganic or organic selenium (Se) $)^{1}$

\begin{tabular}{|c|c|c|c|c|c|c|c|}
\hline \multirow{3}{*}{ Characteristic } & \multicolumn{3}{|c|}{ Treatment $\left(\mathrm{mg} \mathrm{kg}^{-1}\right)$} & \multicolumn{4}{|c|}{ P-value } \\
\hline & \multicolumn{2}{|c|}{ Inorganic selenium } & \multirow{2}{*}{$\frac{\text { Organic selenium }}{0.5}$} & \multicolumn{2}{|c|}{ Treatment $(\mathrm{T})$} & \multirow{2}{*}{ Week (W) } & \multirow{2}{*}{$\mathrm{T} \times \mathrm{W}$} \\
\hline & 0.3 & 0.5 & & $\mathrm{C} 1$ & $\mathrm{C} 2$ & & \\
\hline Doses & $17.04 \pm 1.22$ & $19.53 \pm 1.76$ & $25.23 \pm 1.68$ & 0.0087 & 0.0236 & 0.4907 & 0.9230 \\
\hline CD & $2.33 \pm 0.17$ & $2.40 \pm 0.27$ & $1.52 \pm 0.09$ & 0.4086 & 0.0478 & 0.4136 & 0.6902 \\
\hline TR & $102.24 \pm 7.34$ & $111.54 \pm 10.25$ & $151.40 \pm 10.09$ & 0.0592 & 0.0290 & 0.2839 & 0.9967 \\
\hline
\end{tabular}

$\mathrm{C} 1$ - contrast $1=0.3 \mathrm{mg} \mathrm{kg}^{-1}$ vs. $0.5 \mathrm{mg} \mathrm{kg}^{-1} \mathrm{Se}$; 2 - contrast $2=0.5 \mathrm{mg} \mathrm{kg}^{-1}$ of inorganic Se vs. $0.5 \mathrm{mg} \mathrm{kg}^{-1}$ of organic Se; $\times$ W - interaction treatment and week

Doses - number of seminal doses per ejaculate; CD - cost per seminal dose, in Brazillian Reais (R\$); TR - total revenue, in R\$.

${ }^{1}$ Presented treatment means \pm standard error of the mean. 
presenting the lowest diet cost verified. This result clearly demonstrates the cost effectiveness of using organic Se in boar diets.

The mechanism by which Se increases the number of seminal doses is still largely unknown; however, some molecular mechanisms have been proposed. Selenium plays a role in regulating proliferation and differentiation of the germ cells in testis and suggests that its role is not merely limited as an antioxidant (GSH-Px) or as a structural component of the sperm mitochondrial sheath (Shalini and Bansal, 2006). It has been shown that, besides being involved in the formation of spermatozoa, Se is also needed for normal testosterone metabolism and maintenance of testicular morphology. Glutathione peroxidase has been found in close relationship to the smooth endoplasmic reticulum in the Leydig cells (Murakoshi et al., 1983) and it is possible that the metabolic pathway of testosterone biosynthesis requires protection against peroxidation and is thus affected by a decrease in the activity of this enzyme (Behne et al., 1996).

As already mentioned, studies in which the economic viability of supplementing boar diets with organic Se are still scarce. In this respect, a choice of Se sources for the male diet based on a thorough economic evaluation is of great importance for the swine industry. It has been shown that $\mathrm{Se}$ from organic sources is assimilated much more efficiently compared with commonly used selenite (Mahan et al., 1999). This results in higher Se accumulation in the animal tissues, building a selenium reserve, which can be effectively used during stress conditions (Surai and Fisinin, 2015).

Alternative strategies, such as the use of lower supplementation levels of more bioavailable organic trace minerals, could provide remarkable growth promotion benefits while reducing the quantity of trace minerals excreted. Inorganic sources of copper, zinc, iron, and manganese are the predominant forms used in commercially manufactured premixes primarily due to their low cost and relatively high bioavailability (Whitney et al., 2001). However, organic trace mineral products (proteinates, amino acid chelates, mineral/amino acid complexes, and polysaccharide encapsulated trace minerals) are also used in some swine premixes (Power and Hogan, 2000).

The primary disadvantage of using organic trace minerals in swine diets is that they can be costly. However, most of these forms are at least equivalent and may be more bioavailable than inorganic sources. This means that less of these organic sources are needed to provide the same level of trace mineral nutrition as provided by inorganic sources, resulting in less excretion of excess trace minerals in manure. Unfortunately, more information is needed about the bioavailability of the various organic trace mineral sources to determine replacement rates and the cost effectiveness compared with inorganic sources (Whitney et al., 2001).

In our experiment, boars fed the organic Se-supplemented diet produced $23 \%$ more seminal doses per week compared with boars fed the inorganic Se diet, increasing the total revenue in $26 \%$.

In the present study, we demonstrated that, although the organic source of Se was more expensive when compared with the inorganic source, a $32 \%$ reduction was observed in the cost of diet per seminal dose produced. It should be mentioned that the negative externality was not considered in the economic analysis, requiring, therefore, more studies to evaluate the environmental impact of supplementing swine diets with trace minerals from organic sources.

\section{Conclusions}

Supplementing boar diets with organic selenium increases the number of seminal doses produced, reducing the average cost of the diet, demonstrating, therefore, to be cost-effective in swine operations.

\section{Acknowledgments}

This research was supported by the Fundação de Amparo à Pesquisa do Estado de São Paulo (FAPESP; grant numbers 07/55613-6 and 08/55059-1) and Alltech Inc. and Vet life Veterinary Products.

\section{References}

Behne, D.; Weiler, H. and Kyriakopoulos, A. 1996. Effects of selenium deficiency on testicular morphology and function in rats. Journal of Reproduction and Fertility 106:291-297.

CBRA - Colégio Brasileiro de Reprodução Animal. 1998. Manual para exame andrológico e avaliação de sêmen animal. CBRA, Belo Horizonte.

Celeghini, E. C. C.; Arruda, R. P.; Andrade, A. F. C.; Nascimento, J.; Raphael, C. F. and Rodrigues, P. H. M. 2008. Effects that bovine sperm cryopreservation using two different extenders has on sperm membranes and chromatin. Animal Reproduction Science 104:119-131.

Close, W. H. and Cole, D. J. A. 2000. The boar. p.257-291. In: Nutrition of sows and boars. Nottingham University Press, United Kingdom.

Jacyno, E.; Kawecka, M.; Kamyczck, M.; Kolodziej, A.; Owsianny, J. and Delikator, B. 2002. Influence of inorganic Se + vitamin E and organic $\mathrm{Se}+$ vitamin $\mathrm{E}$ on reproductive performance of young boars. Agricultural and Food Science in Finland 11:175-184.

Kiefer, C. 2005. Minerais quelatados na nutrição de aves e suínos. Revista Eletrônica Nutritime 2:206-220. 
Lopez, A.; Rijsselare, T.; Van-Soom, A.; Leroy, J. L. M. R.; De Clercq, J. B. P.; Bols, P. E. J. and Maes, D. 2010. Effect of organic selenium in the diet on sperm quality of boars. Reproduction in Domestic Animals 45:297-2305.

Lovercamp, K. W.; Stewart, K. R.; Lin, X. and Flowers, W. L. 2013. Effect of dietary selenium on boar sperm quality. Animal Reproduction Science 138:268-275.

Mahan, D. C.; Cline, T. R. and Richert, B. 1999. Effects of dietary levels of selenium-enriched yeast and sodium selenite as selenium sources fed to growing-finishing pigs on performance, tissue selenium, serum glutathione peroxidase activity, carcass characteristics, and loin quality. Journal of Animal Science 77:2172-2179.

Marin-Guzman, J.; Mahan, D. C.; Chung, Y. K.; Pate, J. L. and Pope, W. F. 1997. Effects of dietary selenium and vitamin e on boar performance and tissue responses, semen quality, and subsequent fertilization rates in mature gilts. Journal of Animal Science 75:2994-3003.

Marin-Guzman, J.; Mahan, D. C. and Pate, J. L. 2000a. Effect of dietary selenium and vitamin $\mathrm{E}$ on spermatogenic development in boars. Journal of Animal Science 78:1537-1543.

Marin-Guzman, J.; Mahan, D. C. and Whitmoyer, R. 2000b. Effect of dietary selenium and vitamin E on the ultrastructure and ATP concentration of boar spermatozoa, and the efficacy of added sodium selenite in extended semen on sperm motility. Journal of Animal Science 78:1544-1550.

Martins, S. M. M. K.; De Andrade, A. F. C.; Zaffalon, F. G.; Parazzi, L. J.; Bressan, F. F.; Pugine, S. M. P.; Melo, M. P.; Chiaratti, M. R.; Afonso, E. R.; Moretti, A. S. and Arruda, R. P. 2014. Organic selenium increases PHGPx, but does not affect quality sperm in raw boar semen. Livestock Science 164:175-178.

Martins, S. M. M. K.; Andrade, A. F. C.; Zaffalon, F. G.; Bressan, F. F.; Pugine, S. M. P.; Melo, M. P.; Chiaratti, M. R.; Marino,
C. T.; Moretti, A. S. and Arruda, R. P. 2015. Organic selenium supplementation increases PHGPx but does not improve viability in chilled boar semen. Andrologia 47:85-90.

Murakoshi, M.; Osamura, Y.; Yoshimura, S. and Watanabe, K. 1983. Immunocytochemical localization of glutathione peroxidase (GSH-PO) in the rat testis. Acta Histochemica et Cytochemica 16:335-345.

NRC - National Research Council. 2012. Nutrient requirements of swine. 11th rev. ed. National Academy Press, Washington, DC.

Power, R. and Hogan, K. 2000. Biological chemistry and absorption of inorganic and organic trace metals. p.277. In: Proceedings of Alltech's 16th Annual Symposium Biotechnology in the Feed Industry, United Kingdom. Nottighan University Press, Thrumpton.

Speight, S. M.; Estienne, M. J.; Harper, A. F.; Crawford, R. J.; Knight, J. W. and Whitaker, B. D. 2012. Effects of dietary supplementation with on organic source of selenium on characteristics of semen quality and in vitro fertility in boars. Journal of Animal Science 90:761-770.

Shalini, S. and Bansal, M. P. 2006. Role of selenium in spermatogenesis: differential expression of cjun and cfos in tubular cells of mice testis. Molecular and Cellular Biochemistry 292:27-38.

Surai, P. F. 2006. Selenium in Nutrition and Health. Nottingham University Press, Nottingham, UK.

Surai, P. F. and Fisinin, V. I. 2015. Selenium in pig nutrition and reproduction: boars and semen quality - A review. AsianAustralasian Journal of Animal Sciences 28:730-746.

Whitney, M. H.; Shurson, G. C.; Spiehs, M. J.; Knott, J. S. and Mold, D. E. 2001. Economic evaluation of nutritional strategies that affect manure volume, nutrient content, and odor emissions. Available at: <http://www.extension.umn.edu/swine/components/ pubs/pub009.pdf>. Accessed on: Jan. 04, 2017. 